\title{
Business model and innovation orientations in manufacturing SMEs: An Australian multi-case study
}

\author{
Ronald C. Beckett \\ ronaldbeckett@swin.edu.au | Business School, Swinburne University of Technology, Melbourne, Australia \\ Ross L. Chapman \\ r.chapman@cqu.edu.au | School of Business and Law, Central Queensland University, Rm 6.20, 400 \\ Kent, Sydney NSW, Australia
}

\begin{abstract}
Research studies of SME innovation practice observe some common themes, such as an orientation towards networking, and some differences that may seem activity-related (e.g. production or service). In this paper we suggest the kinds of innovation activity undertaken by an SME will depend on their dominant business model and owner/enterprise attitudes, each one being moderated by purposeful networking. This is illustrated in our review of data from 50 case studies, where combining a CEO narrative analysis with secondary data on the nature of the firm has identified seven generic manufacturing business models. We observe these may be adopted singly or in combination to pursue a competitive advantage, and the dominant business model may change over time as new capabilities are developed and/or in response to market changes.
\end{abstract}

Keywords. Innovation; Business Model; Networks; Manufacturing; SMEs; Discontinuous Innovation.

Cite paper as: Beckett, R., Chapman, R. (2018). Business model and innovation orientations in manufacturing SMEs: An Australian multi-case study, Journal of Innovation Management, www.open-jim.org, 6(1), 111-134. http://hdl.handle.net/10216/111571 


\section{Introduction}

Traditional studies of innovation often consider SMEs as a homogenous group, or may cluster them by traditional industry sector (like services, manufacturing, agriculture). On the one hand, due to their relatively small size, SMEs may be seen as more flexible than large firms, but on the other hand their limited resources may restrict their innovation activities. Our shared history of multiple sector SME involvement (both as practitioners and researchers) indicated there were differences between individual SMEs of similar size in a given industry sector. They seemed to prioritize innovative activities differently and define innovation in different ways. The question was, what might be the sources of this apparent diversity?

As firms identify different ways to compete, traditional sector classifications become blurred. An example is the notion of servitization, which may be defined as 'the innovation of an organization's capabilities and processes to better create mutual value through a shift from selling product to selling Product-Service Systems' (e.g. Visnjic \& Neely, 2011; Neely et al, 2011). Was our informally observed diversity related to the adoption of different business models?

The Oslo Manual (2005), which is used to shape a variety of large-scale innovation surveys, defines innovation as "the implementation of a new or significantly improved product (good, or service) or process, a new marketing method, or a new organizational method in business practices, workplace organization, or external relations. Was our informally observed diversity related to different SMEs focusing on different forms of innovation?

In many parts of the world SMEs are regarded as the engine of regional growth, and there are efforts to stimulate SME innovation. But without an understanding of SME innovation dynamics, such efforts may not be successful. For example, in adapting to changing market and technology conditions, individual SMEs may need different kinds of support at different times, may not have the time or resources to access government initiatives, or there may be a mismatch between the timing of access to such initiatives and when a particular SME needs particular support.

The research question to be explored is: how might SME innovation dynamics be characterized? The paper starts with some observations from the literature related to SME innovation, which leads to three hypotheses. Multiple case studies are explored in the context of each hypothesis, and some conclusions are drawn, offering insights into the underlying dynamics of SME innovation that complement current views expressed in the literature. Some opportunities for further research are suggested.

\section{Some Observations from the Literature}

Consistent with our informal observations, a study of Italian SMEs by Massa and Testa (2008) found there was a higher level of innovation than institutional survey data suggested, and this was linked to how innovation might be defined. Did the survey ask the right questions? The entrepreneurs' perspective saw the process of innovation as 'anything that helped to make money', whilst policy-makers saw SME innovation as 'dream and risk'. It was suggested that academics gave greater importance to the definition of innovation. It was also suggested that these different views could lead to divergent stakeholder goals and contrasting opinions on effective support 
policies. The SMEs interviewed by Massa and Testa stressed that innovation sources are multifaceted, internal and external (involving customers, suppliers and consultants), and not just driven by new technology. These authors also noted the influence of regional networking as an important driver of innovation within the SMEs considered.

\subsection{The Centrality of Networking}

Kickul and Gundry (2002) surveyed 107 US Midwestern small business owners to explore potential linkages between the strategic orientation of the firm and its influence on innovation practice. Analysis of the responses suggested that a small business owner's proactive personality is linked to a strategic orientation for the small firm. Employing a prospector networking strategy influenced the goals and direction of their organizations and the types of innovations developed and implemented.

Another study of 500 SMEs across six European countries found that proactive relationships with suppliers, users and customers facilitated innovation, and that more consistent new product development outcomes were observed in those having links with laboratories and research institutes (Lasagni, 2012). Lewrick et al (2007) asked some 200 technology-driven innovative company managers around the Munich area about the nature and value of their networking activities, In broad terms, personal networking seemed more important to young firms, whilst formal collaborations were more important to mature firms.

Camarinha-Matos, Afsarmanesh and Ollus (2005) reported the findings of a multinational team of researchers working on the ECOLEAD project. The project drew on lessons learned over more than a decade from a multitude of collaboration initiatives. One outcome was a sixty-four page document (Camarinha-Matos et al, 2007) detailing a reference framework relating to the establishment and operation of collaborative ventures. It was noted that collaborations may be established for long-term strategic purposes or to achieve a shorter-term goal. It was also noted that the term 'collaboration' was used in a number of diferente contexts ranging from informal networking through conditional cooperation to full and transparent knowledge-sharing collaboration. The point we wish to make here is that regardless of the extent of collaboration being considered, it was observed that networking involving communication and information exchange was a foundation activity

Gilmore, Carson and Grant (2001) explored how SMEs used networking in their marketing activities. They noted the practices adopted may be determined by some attributes of the entrepreneur or owner/manager; and may beinfluenced by the size and stage of development of the firm. They linked networking and learning that influenced decision-making, observing that as networking activities moved between personal and business relationships, so did the nature of decision-making. Social networking might only provide partial information, and call for the use of intuition. Business contacts and networking could inform more rigorous decision-making. Saunders et al (2014) researched the role of networks in supporting SME learning, noting the need for opportunities and time for reflection as a means of stimulating personal learning and that time spent engaging in informal conversations with peers be considered as an investment not a cost.

O'Donnell (2014) interviewed 30 small firm owner-managers in Ireland to explore the nature of 
networking undertaken and how networking influenced marketing outcomes. It was found that networking could have a multitude of facets. Sixteen contributions were identified, including access to new knowledge of various kinds, and the identification of new cooperation and market access possibilities. Different connections were made with different people at different times to understand the firms' external business environment and formulate or change marketing plans. Some activities sought feedback on the firm's competitive position, some sought to identify new opportunities, some sought to identify new practices.

Ceci and Iubatti (2012) explored the role of personal relationships formed in SME networks in facilitating innovation diffusion. They suggested that the co-existance of personal and professional relationships modified inter-firm dynamics, creating a space where traditional innovation activities could take place in an unusual way.

Alguezaui and Filieri (2010) have observed that different kinds of social networks support different aspects of innovation. Sparse networks support the 'fuzzy front end' knowledge sharing and incremental innovation, whilst dense networks having strong interdependencies better support radical innovation. Whilst an SME firm may be established to commercialise a radical idea, once established such firms may need to pursue incremental innovation on many fronts.

In summary, these observations introduce the concept of purposeful networking as a strategic mindset where two-way personal exchanges of information may enhance competitive positioning or where such exchanges may lead to cooperative working arrangements. In an innovation context, purposeful networking may identify an incentive to innovate, identify new ideas, or at other times be used to test ideas. Networking is generally seen as important, but is undertaken in different ways and for different purposes at different times. It takes time, but the benefits accrued include obtaining leverage from new ideas and enhancing the absorptive capacity of the firm (Konsti-Laakso et al, 2012)

\subsection{Innovation is Personal}

Organizations may seek out innovative ideas, but if there are no champions, if no-one takes ownership of a particular idea, innovation does not happen. In addition to the idea champion, there must be champions of the innovation process, providing linkages as the idea progresses, and there must be management champions that support the innovator and provide resources (Unsworth, Mazzarol and Reboud, 2009; Coakes and Smith, 2007; Vincent, 2005; Kelley and Lee, 2010).

In a study of 360 UK SMEs Blackburn et al (2007) found that owner-managers who saw themselves as innovators or change agents were more likely to stimulate growth, but the size (larger) and age (maturity) of the firm had a stronger influence.

Terziovski (2010) analysed survey data from 600 Australian manufacturing SMEs. He observed the innovation processes within small firms seemed to be more organic than their larger counterparts, and suggested their performance may improve if they mirrored large firm practice. This seems consistent with Australian Bureau of Statistics data showing level of innovation activity in Australian firms generally increases with firm size.

Hickman and Raia (2002) observed that both divergent thinking and convergent thinking styles are necessary for successful innovation. Without some divergent thinking an organisation will 
lack the creativity and passion required to make breakthrough innovations; and without some convergent approaches the organisation will lack the perception and persistence to realize the potential of their innovative ideas.

A study of 256 Scottish firms by Chang, Hughes and Hotho (2011) suggested that SMEs develop a capability to dynamically balance divergence and convergence in mediating between internal organisation and external environmental conditions. The implication is that sometimes SMEs may focus on seeking new ideas, and sometimes on deploying innovative ideas.

In summary, what we take from this is that in firms of all size, someone needs to take ownership of an innovative idea. But to facilitate its deployment, it is necessary appreciate what is required at different stages and to orchestrate the activities of a variety of actors as an innovation evolves, which requires distinct capabilities and skills (Ritala, Armila and Blomqvist, 2009).

\subsection{Business Models and Innovation}

Implementing an innovation has to make business sense. Chesborough (2010) suggests: 'a mediocre technology pursued within a great business model may be more valuable than a great technology exploited via a mediocre business model' (p354). Teece (2010, p 179) describes the concept of a business model as follows:

A business model articulates the logic and provides data and other evidence that demonstrates how a business creates and delivers value to customers. It also outlines the architecture of revenues, costs, and profits associated with the business enterprise delivering that value. Companies can adopt business models pioneered in one space into another.

In reviewing the extensive literature on business models, Mason and Spring (2011) found that the three key elements consistently identified as the fundamental components of business models are: 1) the technology (or technologies) that make up the product/service offering, its delivery and management; 2) the market offering (what is actually offered to the customer and how this is done); and 3) the network architecture (the configuration of buyers and suppliers that make the market possible). The third component has been somewhat overlooked by some sections of the business model literature, where a firm-level strategic focus has dominated research on the business model concept. Other authors (Loss and Crave, 2011) have extended business model constructs to include dynamic alliances between firms, referred to earlier as collaborative networks.

Zott and Amit (2010) suggest that the purposeful weaving together of interdependent activities those performed by the firm itself or by its suppliers, partners and/or customers - is the essence of the business model design. Osterwalder and Pigneur (2009) have observed that for many firms, a business model may be so embedded in routine activities, it has to be brought to the surface and mapped out to clarify the constituent parts and how they are related. It is integral with day-today operations and there may be a dominant model in a particular sector (e.g. manufacturing or service). These authors have developed an approach called the business model canvas to develop a picture of just how a firm's business model is constructed. Major constructs are the value proposition, infrastructure, customers and finances.

A concept diagram drawing together several elements from business model research that may be used to investigate and analyse both manufacturing and service business models is presented 
in Figure 1. Many business model representations are oriented towards good-producing firms. However as noted by Kastelli et al (2013), firms pursuing a servitization strategy need to rethink their business models. Both these authors and Maglio and Spohrer (2013) cite the utility of service blueprinting in understanding a services-oriented view. This concept considers activities as front-of-stage or backstage (Bitner, Ostrom and Morgan, 2008). Figure 1 retains the concepts of value proposition and market engagement found in the business model literature, adding expectations to be met in such engagement. The market perspective is modified slightly by referring to beneficiaries. This reflects our experience that the immediate customer of a firm may not be the end beneficiary, and this has to be taken into account. An example is where the direct customer is the purchasing department of a large organization, representing the end users. Here relationship building with both the direct buyer and the end user may be beneficial as a kind of 'front office' activity. However the creation and delivery of customer value is supported by back office infrastructure in carrying out tasks to met specific requirements. The financial arrangements referred to in the business model literature generally consider ways of building revenue and constraining costs. It is our observation that, particularly in collaborative environments, the equitable distribution of margins amongst partners also needs to be considered, as does return on investment by each participant. The authors have previously used this model with several different groups of SME managers to discuss concepts relating to business model operation and innovation.

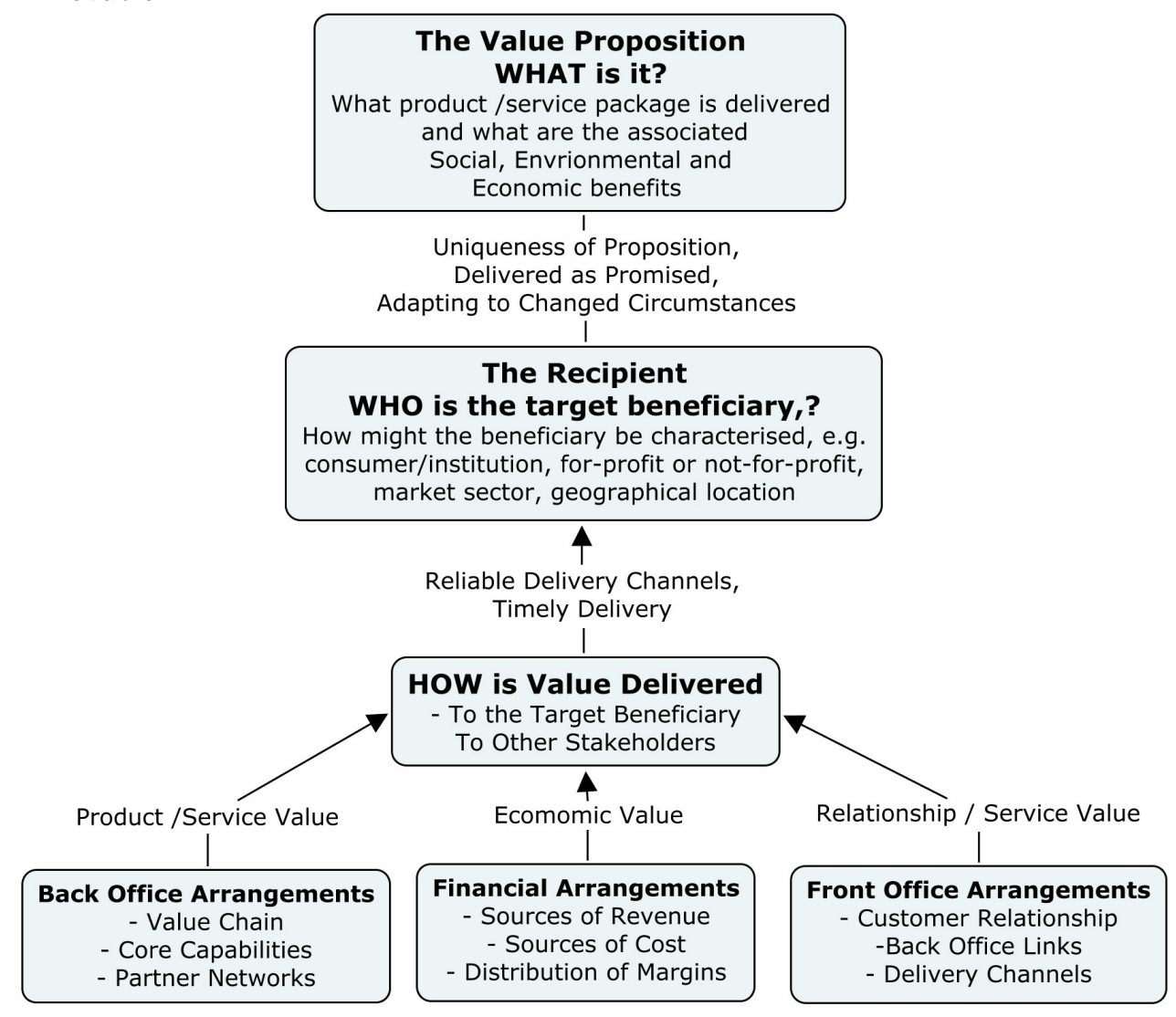

Fig. 1. Business Model Analysis Plan 
Sabatier et al (2010) drew on an analogy between the business model concept and a recipe. They suggest a firm may have more than one 'recipe' at their disposal to enable the establishment of a complementary set like a multi-course 'dinner'. The biotechnology firms they studied over a period of ten years commonly used two or three of these in concert, where the choice seemed to relate to the firms risk appetite and acceptance of interdependencies on other firms. Barjack et al (2013) reviewed 67 case studies of enterprise Business Model Innovation from Europe, the USA and Asia. These authors then clustered the 67 cases into three families where the first two were perceived as representing more radical innovation activity, and the third, more incremental or architectural innovation activities:

1. All-round goods innovators: with a focus on new products (and less on services); with associated process and market innovations, but with revenue models remaining unchanged.

2. Revenue model innovators: with a focus on service and product pricing innovations and revenue model changes, but very little product innovation. This is observed in many ecommerce arrangements

3. Small-scale innovators: This largest group in the study mainly introduced new services, with a focus on work arrangements, market channels and support activities.

In summary, the focus is on delivering value to customers and extracting value for the firm, and this may be achieved in a number of ways - there may be different innovation scenarios associated with a particular company at a particular time. If customer expectations change, the business model may also have to change, or a supplementary model be established.

\subsection{SME innovation framework conditions}

Drawing on the above observations from literature related to SME innovation, and in particular the summaries at the end of sections $2.1-2.3$, we put forward three propositions

1. Innovation is predominantly a personal process in such businesses - largely influenced by one or two key entrepreneurial individuals. This 'personal' innovation is largely influenced by prior experience related to dominant business models in the relevant sector, and an ability to orchestrate different innovation processes.

2. Both the need to innovate and the scope for innovation are influenced by what is learned through a strategic orientation towards social or organisational networking, recognising that such networking has multiple dimensions. We use the term 'purposeful' networking to represent a mindset and an activity underpinning all such networking that provides benefits to the organization and creates connections beyond the organisation.

3. Current and desired competitive positioning, and the role of innovation, is driven by matches between the dominant business model(s) and social/organisational networking observations that sense the extent of fit with the business environment. 
A framework illustrating the constructs and connections considered in the above propositions and developed from our review of the literature is shown in Figure 2 below.

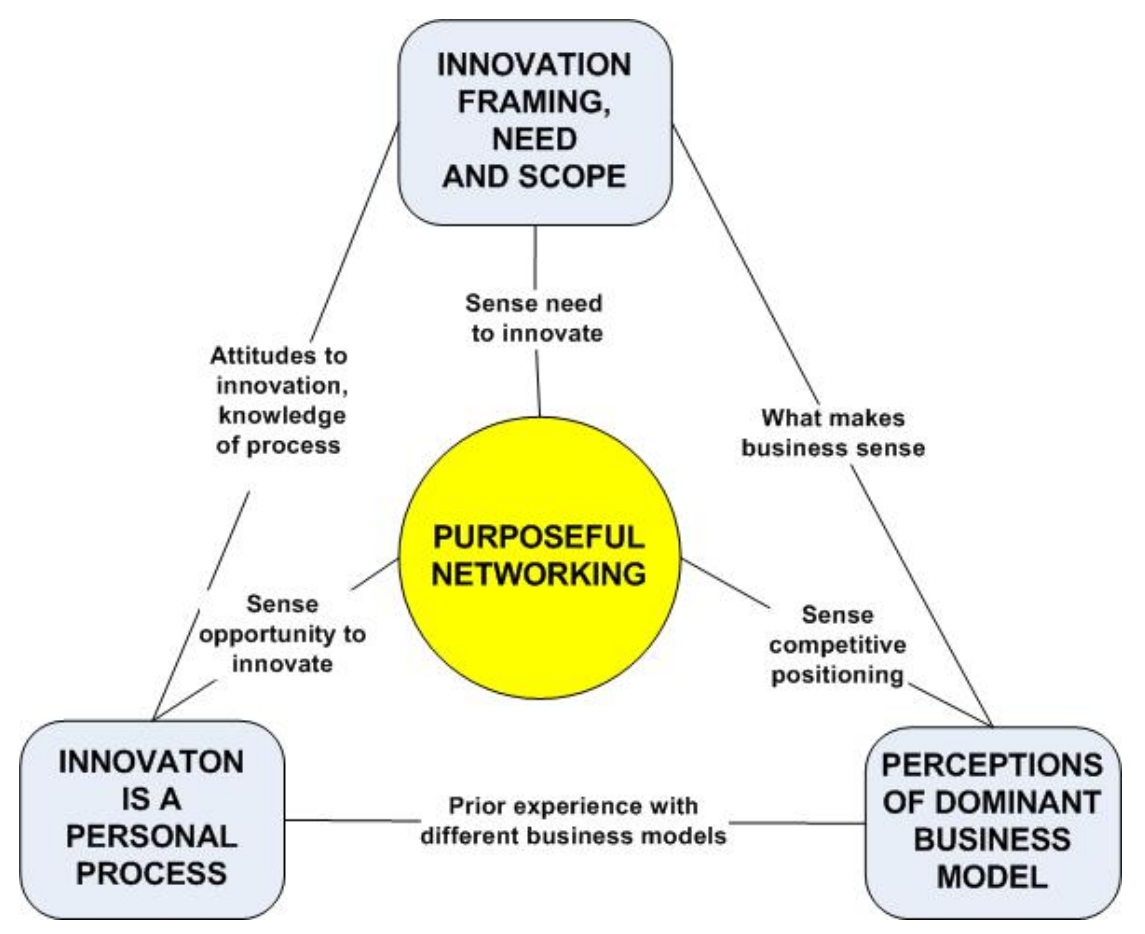

Fig. 2. Conceptual Framework for the Research

\section{Research methodology}

We wanted to investigate why apparently similar SMEs might assign different priorities to different kinds of innovation and why they might define innovation in different ways. We identified three propositions from our literature survey. We adopted a case study methodology, which according to Yin (2014) is appropriate in exploring questions of how and why. Our unit of study was the individual SME. We drew on case study data available to us where each case involved an exploration of SME innovation practice. We drew on viewpoints from multiple cases as a form of triangulation considering our 'why' questions.

Over the last ten years or so we have accumulated transcripts (generally from CEO interviews) and secondary data related to SME innovation in more than 50 cases. The case study material was collected in connection with four government or industry body programs that sought to share innovation best practice or identify how innovative SMEs could be supported in their efforts. These cases included manufacturers from different sectors plus some firms focused on providing services to manufacturers. Sectors covered included tool-making, packaging, auto components, electronics, shipbuilding, building products, pharmaceuticals and food manufacturing. The case 
study firms had been selected on the basis of their reputation as judged by government or industry association observers who had worked with them.

Case study data was assembled through textual analysis of transcribed interview data and combined with secondary company materials and observational data recorded during company visits. We have reviewed these cases to draw out how the SMEs managers described what they thought was innovative, what they actually did, and what they perceived the dominant business model in their organization. In some case we had longitudinal data available, and could see if firms changed their business model(s) over time. The sources of data are shown in Table 1. All of our case study firms had been in business for more than ten years.

Table 1. Data sources

\begin{tabular}{|c|c|}
\hline Data Source & Data Set \\
\hline $\begin{array}{l}\text { Transcripts from a } 2001 \text { industry workshop on } \\
\text { the diffusion of innovation }\end{array}$ & $\begin{array}{l}17 \text { SMEs gave their definitions of innovation and } \\
\text { provided examples of how they pursued the } \\
\text { process of innovation }\end{array}$ \\
\hline $\begin{array}{l}\text { A } 2008 \text { commissioned study of innovation in the } \\
\text { NSW manufacturing sector }\end{array}$ & $\begin{array}{l}\text { There were interviews with CEOs and senior } \\
\text { managers of } 22 \text { firms. Content analysis of the } \\
\text { transcripts showed the dominant themes as } \\
\text { money and product, followed by manufacturing, } \\
\text { then government. }\end{array}$ \\
\hline A 2009 study of five innovative Advanced & All 5 firms provided contract manufacturing \\
\hline Manufacturing firms nominated by their & services, and one had its own product. The SME \\
\hline industry association. & $\begin{array}{l}\text { CEOs and senior managers gave their views of } \\
\text { what innovation meant for them. }\end{array}$ \\
\hline A 2011-14 study of food sector SMEs & $\begin{array}{l}\text { Interview transcripts and secondary data from } \\
11 \text { food sector firms. }\end{array}$ \\
\hline
\end{tabular}

As recommended by Eisenhardt (1989) for cross-case analysis studies, we have used a similar classification of the various cases involved in our study. We have used the key business model characteristics as the classifying element (see Table 2 below). Answering the questions posed in the boxes shown in Figure 1 through analysis of the interview transcripts retained from the studies listed in Table 1 allowed an effective classification of the business model constructs adopted in the various firms involved.

We briefly explored what might have changed in our case study firms since we collected the original data. A web search on the 17 firms involved in the 2001 workshop and the 5 firms in the 2009 study showed that: six had been acquired by overseas businesses; four had grown substantially through exports; and some had grown through partnerships or mergers. Most had changed their business models.

\section{Findings}

The transcripts from the firms were clustered according to what they said they did and applying the analysis framework shown in Figure 1 to the retained transcripts rather than the industry 
sector they operated in. Table 2 shows the outcome: the identification of seven characteristic business models with quotes from representative firms on how they viewed innovation. The seven characteristic business models were: contract manufacturing; technology development; product design and manufacturing; services supporting manufacturing; manufacturing and distribution; product-service bundling; and services.

Table 2. Classifications according to business model type

\begin{tabular}{|c|c|c|}
\hline Type & $\begin{array}{l}\text { Characteristic Business } \\
\text { Model }\end{array}$ & Brief description / Representative quote \\
\hline 1 & Contract Manufacturing (4 firms) & $\begin{array}{l}\text { Well innovation for me is bringing on the latest } \\
\text { technology and using those technologies in a coordinated } \\
\text { way to bring in an outcome that provides a competitive } \\
\text { advantage to us against our competition }\end{array}$ \\
\hline 2 & $\begin{array}{l}\text { Technology Development ( } 8 \\
\text { firms) }\end{array}$ & $\begin{array}{l}\text { These firms saw technology development as a key to } \\
\text { their competitive position, and had a focus on } \\
\text { intellectual property. Some of them also manufactured } \\
\text { the products they developed, and some developed } \\
\text { processes for making their product to offer an IP/tool } \\
\text { bundle. "I think of it in two separate ways. One is a } \\
\text { formal way where we use innovation to create intellectual } \\
\text { property in the form of patents or trade secrets that we } \\
\text { use in our work. At the same time it means trying to do } \\
\text { everyday things faster, cheaper and better than our } \\
\text { competition throughout the world." }\end{array}$ \\
\hline 3 & $\begin{array}{l}\text { Product Design and } \\
\text { Manufacturing ( } 2 \text { firms) }\end{array}$ & $\begin{array}{l}\text { "I see innovation as not only applying to new ideas, but } \\
\text { to the whole process from product design through } \\
\text { production through and including the culture of the } \\
\text { company - a 'nothing is impossible' attitude. For example } \\
\text { most of our competitors are highly vertically integrated } \\
\text { whereas we are not. We have turned this into a positive, } \\
\text { providing flexibility being able to work with a multitude of } \\
\text { suppliers compared with our competitors to design to } \\
\text { cost." }\end{array}$ \\
\hline 4 & $\begin{array}{l}\text { Services firms supporting Manuf. } \\
\text { (1 firm) }\end{array}$ & $\begin{array}{l}\text { "For us this means the adaptation of an idea from one } \\
\text { industry to another industry. A solution that has been } \\
\text { applied somewhere and we see the links between that } \\
\text { industry and we can translate that solution. So for us it's } \\
\text { not about being revolutionary, but evolutionary." }\end{array}$ \\
\hline 5 & $\begin{array}{l}\text { Manufacturing and Distribution } \\
(1 \text { firm })\end{array}$ & $\begin{array}{l}\text { This firm operated manufacturing and multiple brand } \\
\text { retail outlets (selling their own and other firm's } \\
\text { products) as separate Divisions. "The commitment to the } \\
\text { steady and gradual improvement in both process and } \\
\text { product in response to customer needs" }\end{array}$ \\
\hline 6 & $\begin{array}{l}\text { Product-Service Bundling (1 } \\
\text { firm) }\end{array}$ & $\begin{array}{l}\text { We provide long term leases for commercial carpet } \\
\text { covering replacement and maintenance aspects of the } \\
\text { floor covering. }\end{array}$ \\
\hline
\end{tabular}




\begin{tabular}{lll}
\hline Type & $\begin{array}{l}\text { Characteristic Business } \\
\text { Model }\end{array}$ & Brief description / Representative quote \\
\hline 7 & Services (5 firms) & "We are a services organization so we don't necessarily \\
& create anything unique from a product perspective \\
& however we apply innovation in grouping our services in \\
& such a fashion that they differentiate us in the customers \\
& eyes. So from our perspective we need to take training or \\
& a type of application development presented in a fashion \\
& that makes it appealing. We don't do anything different \\
& from our competitors, but we show how we can deliver \\
& value" \\
\hline
\end{tabular}

The five Advanced Manufacturing firms from the 2009 study were all viewed as innovative by their peers. The CEOs of these firms participated in individual structured interviews regarding their definition of innovation, and how it was practiced in their firm. At the time of the original interviews, all provided contract manufacturing services, and one had its own product. Their external networking was with customers, through industry associations/networks, trade shows, marketing missions and the internet. Since the original interviews, the global financial crisis had clearly impact on the businesses. One acquired the business of another. All now have a specialized product of their own, albeit acquired by different pathways (acquisition or development). Two of them have added repetitive contract production to their repertoire, and another is specializing in the production of micro-tooling. Those interviewed expressed some different views about the meaning of the word 'innovation' as presented in Table 3. From the broader discussions held with participants it became clear that a culture supporting innovation exists, and that to these firms innovation is a technologically focused process of continual improvement.

Table 3. Definitions of innovation from Advanced Manufacturing Firms

\begin{tabular}{|c|c|}
\hline Respondent & Definition of innovation \\
\hline 1 & $\begin{array}{l}\text { I don't use the word innovation. And I tell you, the longer governments keep using } \\
\text { these 'clicky' words, the real world with which you're dealing here, manufacturers, } \\
\text { won't get on board to the degree they perhaps should. }\end{array}$ \\
\hline 2 & $\begin{array}{l}\text { Well innovation for me is bringing on the latest technology and using those } \\
\text { technologies in a coordinated way to bring in an outcome that provides a } \\
\text { competitive advantage to us against our competition. }\end{array}$ \\
\hline 3 & Trying to look at new technology and new ways of doing things and time saving. \\
\hline 4 & $\begin{array}{l}\text {...if you take the (meaning) straight out of the dictionary it is simply an } \\
\text { introduction of change... If you talk about creative change and doing things } \\
\text { creatively in your business to get a better business result - and that's the definition } \\
\text { of the word innovation. And it's [innovation] a good idea and then turning it into } \\
\text { something to make money. In a way, it's also always looking forward with a } \\
\text { commercial mind. Innovation for the sake of innovation to me is not innovation. } \\
\text { With innovation you have to create wealth somehow. }\end{array}$ \\
\hline
\end{tabular}




\begin{tabular}{cl}
\hline Respondent & Definition of innovation \\
\hline $\mathbf{5}$ & Innovation is an evolutionary event rather than a new bright spark. Not a \\
& revolutionary new idea just improvement...simply trying new things. Innovation \\
& doesn't necessarily spell success or good things. It's just a day-to-day thing that you \\
& try to implement. \\
\hline
\end{tabular}

Many CEOs expressed the view that their own networking was the key driver for innovation in their organization. The following quote from one of these CEOs is typical of this perception.

I tend to run my organisation based on past experience and I guess through models I've learned through doing masters degrees and stuff like that...sometimes you just don't know where you get knowledge from to make decisions and I guess its just its just the basis of the experience I've had in life to make those organisational changes.

Table 4 provides an overview of the approach to innovation taken by a sample of the firms interviewed in the 2008 manufacturing survey illustrating that a variety of forms of innovation and business models may be in play. Note that one of these firms had started to introduce a Product-Service bundling business model.

Table 4. Approaches to business and innovation adopted by a selection of the SME CEOs interviewed

\begin{tabular}{ll}
\hline Company & Business Description and Approach to Innovation \\
\hline Carpet & Modular carpet manufacturers with strong environmental sustainability focus. \\
Manufacturer & $\begin{array}{l}\text { Product innovation, but also business model innovation through } \\
\text { "servitization" (providing leases for long term commercial carpet use covering } \\
\text { replacement and maintenance aspects of the floor covering). }\end{array}$ \\
$\begin{array}{l}\text { Robotic Solutions } \\
\text { Provider }\end{array}$ & $\begin{array}{l}\text { Experts in tailored automatic and robotic solutions, including design, } \\
\text { manufacture, project management through to implementation, commissioning } \\
\text { and on-going service and support. }\end{array}$ \\
& Technical product focused, but also service innovation through improved \\
& customer responsiveness - providing technology-driven tailored solutions \\
Sleep Disorder & Dolving specific customer. \\
Product & treatment manufacturer, and marketer of products for the diagnosis and \\
Manufacturer & disorder solutions, but also process innovation to improve production \\
efficiencies for their products. \\
Semiconductors \\
Manufacturer & $\begin{array}{l}\text { Designs and manufactures microelectronic devices using unique configurations } \\
\text { of semiconductor process technologies. High tech product and process }\end{array}$ \\
& innovation, with a focus on the latter, because much of the new product \\
& technology is sourced from Universities of overseas partners. Close connection \\
& with several key Universities, and key managers are strongly networked. \\
& Defines innovation as "Turning an idea into money."
\end{tabular}




\begin{tabular}{|c|c|}
\hline Company & Business Description and Approach to Innovation \\
\hline $\begin{array}{l}\text { Welding and } \\
\text { Engineering }\end{array}$ & $\begin{array}{l}\text { Welding specialist with strong core competencies in stainless steel, aluminium } \\
\text { fabrication \& sheet-metal work, plus design, manufacture \& installation }\end{array}$ \\
\hline Specialist & $\begin{array}{l}\text { complex life support systems worldwide. Process innovation, but also some } \\
\text { product innovation through adapting existing technologies to provide } \\
\text { innovative solutions for customer problems. }\end{array}$ \\
\hline $\begin{array}{l}\text { Hearing Solutions } \\
\text { Provider }\end{array}$ & $\begin{array}{l}\text { Design, develop, manufacture and market a range of implantable hearing } \\
\text { solutions to solve hearing loss. }\end{array}$ \\
\hline Manufacturer & $\begin{array}{l}\text { Technology-focused product innovation driven by a large } R \& D \text { function } \\
\text { (about } 12 \% \text { of revenue goes to R\&D) but also some process innovation to } \\
\text { improve productivity and efficiency of manufacturing processes. }\end{array}$ \\
\hline Aerospace & A diversified supplier of electronic systems and simulation technology solutions \\
\hline Electronics & for aerospace, defence and commercial markets A combination of product \\
\hline Supplier & $\begin{array}{l}\text { innovation driven by customer needs and business model innovation driven by } \\
\text { changing market demands such as reverse logistics that drives reuse and } \\
\text { recycle of products following customer use. }\end{array}$ \\
\hline Steering & A technology provider in automotive steering, from concept development and \\
\hline Technology & engineering design, through to marketing and intellectual property protection. \\
\hline Supplier & $\begin{array}{l}\text { Mostly design innovation - they licence their IP and provide equipment for its } \\
\text { manufacture all over the world. }\end{array}$ \\
\hline
\end{tabular}

Table 5 provides a longitudinal view of a food sector manufacturer, Moira Macs, that had changed its business model over time. The evolving business models adopted have been linked back to the various characteristic business model types described in Table 2. In this case, the CEO's view of innovation was:

I think it is any transformation of a product or process that uses one or more unique inputs. I think you have to be fairly broad with it. It can be a new process or an incremental improvement that improves efficiency of product, process or people, but it seems to involve a unique output or strategy

Some other cases in the food sector set followed a similar path - starting in food retailing or food service, and then moving into manufacture. Yet others have followed a 'paddock-to-plate' model moving from meat production to direct consumer marketing with additional value-added products.

Table 5. A Food Sector Case Study: Evolving Business Models 


Business Model
1. Retailing (Type 7 in Table
2)

2. Retail plus own product manufacture (Type 4 in Table 2)

3. Contract manufacturing (Type 1 in Table 2)

4. Own product design and Manufacturing for wholesale distribution (Type 3 in Table 2)

\section{Background}

Moira Macs was established in 1983, initially operating a fresh poultry retail facility in a regional town market. Prior to that, the owners and worked in Europe for some time, where they were impressed by the variety of ready-to-cook poultry products (such as Chicken Kiev). They introduced such product to their regional town where they were regarded as novel. In establishing the business, they were able to draw on decades of family experience running butchers shops

They started making small goods and a cooked smoked chicken product as a sideline. These proved so popular, Moira Macs established a small manufacturing facility. This required knowledge of additional regulatory requirements and the installation of a packaging facility. The retailing business was sold in the early 1990's as there was increasing competition with low barriers to entry for such a business, and there were opportunities to grow the manufacturing business, with a specialization in cooked, ready-to-eat products for the wholesale trade.

In the mid 1990's, the firm established a strategic partnership with a national small-goods firm, undertaking bulk contract manufacturing, and this continues today. There are also strategic partnership arrangements with two other large firms. Through this partnership, Moira Macs also established contacts in the large retail sector, where the firm started promoting its own brand products more actively over the past decade. . Moira Macs also makes a variant of its product for sale under a supermarkets own brand. In 1995, the firm gained ISO 9000 QMS accreditation (one of the first in its industry sector)

In 2011 Moira Macs installed a new kind of cold pasteurization process called hyperbaric pressure pasteurization. Some support was provided by the CSIRO Food Innovation group, who had good technical knowledge about the process. A CSIRO researcher was located at Moira Macs for a period of time. This has been a two-way arrangement where practical experience gained has been fed back to the research team. This process allows the firm to develop product that is free from chemical flavorings and preservative, and follow a niche market trend where this is valued. There are some staff dedicated to 'recipe' development, which involves both flavor formulation and cooking/packing process arrangements. Moira Macs has long-standing relationships with regional suppliers, and as the business has grown, has established a relationship with a national supplier. The firm is an active member of a regional poultry cluster group that works cooperatively on specific projects. 


\section{Discussion}

In the following discussion we comment on each of the elements shown in Figure 2. Many of our observations are consistent with those of others reported in the literature.

\subsection{Innovation is personal}

We have proposed that innovation in SMEs is largely a personal process (proposition 1), driven predominantly by one or two key people in the organisation. This may vary as the size and maturity of the SME increases; however we observed the social networks and entrepreneurial drive of these key owners/ managers is an essential aspect of innovation within an SME. Peltier and Naidu (2012) have shown that '... social networks for small businesses change as firms transition from startup to growth and beyond. Personal networks were most important during startup, with other social networks growing in contact frequency and importance over time.' Other researchers (Ceci and Iubatti, 2012) have shown the existence of personal relationships between partners in SME networks facilitates the success of the diffusion and adoption of innovation, increasing the firms' competitiveness.

\subsection{Purposeful networking}

By 'Purposeful Networking' we mean strategically choosing to access many different kinds of networks for different purposes at different times (proposition 2). Examples we observed were: (i) participation in government or industry association facilitated networks for business improvement; (ii) involvement in university or other research institution led research exchange networks; (iii) use of social media technologies such as LinkedIn or Facebook to source new partners, suppliers or ideas for business development and improvement; and (iv) use of sophisticated IT-driven platforms for collaborative product development between SMEs, consistent with the observations of Shamsuzzoha, et al (2016). Networking has long been recognized a valuable source of external ideas for firms seeking to innovate, whether they are manufacturing or service-based. Recent research has strengthened this support (e.g Ci-Rong Li et al, 2014). Alexander and Childe (2013) considered the contribution of tacit knowledge transfer processes between universities and business to innovation within the businesses. They concluded that tacit knowledge transfer through face-to-face interaction is most successful, and that it is dependent upon the context, content and process of the knowledge transfer. This rings true in our studies as well, where we found that those SMEs who were more proactive in considering innovations to their substantive business model demonstrated a much greater involvement in external networks. The plant manager of the carpet manufacturer who had developed an innovative product-service system to replace its traditional manufactured product stated:

Again we have contacts at universities of course. So [we network with] academic institutions. I mean the management here, most of it has been around longer than I have, so they have obviously established networks through their history. We operate through the Carpet Institute which is based in Melbourne. We have four members of that, so there's obviously the networking that that provides, both within and without, because effectively, they lobby on behalf of the carpet industry, the industry as a whole. 


\subsection{Perceptions of dominant business models}

We identified six different business models (see Table 2) that were directly associated with manufacturing sector SMEs plus a services model, and there may be variants of each model (proposition 3). The study by Barjack et al (2013) referred to earlier, illustrated that thinking about a change in the firm's business model first can reveal associated product/process/marketing/organizational innovation to implement such a change. In the cases examined in this paper, some firms changed their business models over time (e.g. see Table 5), but establishing parallel business models was also an increasing trend, consistent with the observations of Sabatir et al (2010). Examples are contract manufacturers acquiring their own product, and own product manufacturers taking on some contract manufacture. Variants of a business model related to volume and variety were also observed in our data set (e.g. tool-making firms c.f. routine production firms). Volume / variety combinations influence the nature of production (Chapman et al, 2008) and of service (Silvestro, 1999) business models as each combination represents a different value proposition, and may require some different infrastructure.

\subsection{Linking factors}

In Table 6 we use the Moira Macs case study (as described in Table 5) to illustrate the Figure 2 linking factors at work, and how they influenced business positioning. The linking factors are: 1. Sensing competitive positioning; 2. What makes business sense; 3. Prior experience with different business models; 4 . Sensing the opportunity to innovate; 5 . Attitude to innovation and knowledge of processes; 6 . Sensing the need to innovate.

Table 6. Examples of linking factor influence

\begin{tabular}{ll}
\hline Figure 2 Linking Factor & $\begin{array}{l}\text { Impact on Business Positioning in the Moira } \\
\text { Macs Case }\end{array}$ \\
\hline Sense competitive positioning & $\begin{array}{l}\text { Identification of growing competitiveness resulted in } \\
\text { withdrawal from the retailing business and a move } \\
\text { into manufacturing } \\
\text { Quitting retailing introduced a focus on process } \\
\text { innovation }\end{array}$ \\
What makes business sense & $\begin{array}{l}\text { Family business experience supported company } \\
\text { start-up, later experience in contract manufacturing } \\
\text { Prior experience with different } \\
\text { business models }\end{array}$ \\
& $\begin{array}{l}\text { manufacturing } \\
\text { Initial contract manufacturing led to linkages with } \\
\text { supermarkets supporting launch of own brand }\end{array}$ \\
Sense opportunity to innovate & Use of design control and continuous improvement \\
aspects of ISO 9000 to manage innovation projects
\end{tabular}




\begin{tabular}{ll}
\hline Figure 2 Linking Factor & $\begin{array}{l}\text { Impact on Business Positioning in the Moira } \\
\text { Macs Case }\end{array}$ \\
\hline Sense need to innovate & Identification of a growing demand for \\
& $\begin{array}{l}\text { preservative-free food led to the introduction of a new } \\
\text { cold pasteurization process }\end{array}$ \\
\hline
\end{tabular}

Gilmore, Carson and Grant (2001) noted linkages between networking activities and learning. We have speculated that the interaction between sets of these linking factors may be viewed as alternative innovation mode two-way learning loops in relation to the linkages in our model (Figure 2). The most common loop (left side) is: - sense a need, sense an opportunity, act using personal and enterprise knowledge (e.g. market-driven innovation). Or in a reverse flow: sense an opportunity, act using personal and enterprise knowledge, sense a need/application (e.g. technology-driven innovation). Another (right side) is: sense a need, sense competitive positioning, adapt the business model to make business sense; or identify a need, frame a suitable business model, enhance competitive positioning (e.g. business model innovation). A third (bottom side) is more strategic in nature: sense an opportunity, draw on prior experience with different business models, enhance competitive positioning (business model innovation) - or, sense competitive positioning, adapt a business model drawing on prior experience, identify new opportunities (e.g. organisational innovation).

\subsection{Innovation framing, innovation need and scope}

For firms of all size, the dominant purpose is making money and this means the expenditure of time and resources on innovation has to make business sense. The Business Council of Australia (BCA) is an association of Chief Executives of 100 of Australia's leading corporations. As with our SMEs, case studies of 19 member firms revealed different discourses relating to innovation, depending on the nature of the firm's business. The common view was that innovation can be defined as the:

'.... application of knowledge to create additional value and wealth. There are times when this involves the application of new knowledge, but novel outcomes could also be achieved by applying existing knowledge in new and different ways. Innovation occurs across a business, customer value is central, and human capital is crucial.'

We see this as consistent with the views expressed in our SME data set. The BCA suggested innovation management practice will change in the 21st century, moving from a product focus to a customer solution focus. The BCA noted that in industries such as processed food, groceries, and consumer electronics, the pressure to build and retain market share is having the effect of making product life cycles shorter. An example from our data set is a software/microchip design firm:

In the marketing area, we have we have taken an innovative approach to the development of our IP using an open source model. We throw our IP out to a wider community, and have 
thousands of people working on its application and development. We then take that back and enhance our asset base in the application of technology, not the ownership of technology.

We suggest that what identifies a firm as innovative may need to be reconsidered. The Oslo Manual defines innovation using a structural view that does not include the word value. Perhaps it is assumed businesses would not undertake innovation that does not make business sense. Early editions focused on technological product and process innovation in manufacturing. In the 2005 edition, the scope of what was considered as innovation was expanded to include marketing and organisational innovation. Mergers and acquisitions are not considered to be organisational innovations. A new section also included reference to innovation linkages. Innovation diffusion is considered from the perspective of what is new to the firm, but not what happens within the firm. The final definition of innovation adopted was 'An innovation is the implementation of a new or significantly improved product (good or service), or process, a new marketing method, or a new organisational method in business practices, workplace organisation or external relations.'

Our argument here is that innovation needs to enhance the value proposition offered by the firm and beneficially change the financial arrangements - adapting or reinventing the firm's business model. The Oslo manual also states that '.. . an innovation-active firm is one that has had innovation activities during the period under review, including those with ongoing and abandoned activities.' We see this temporal limitation as potentially masking real innovation dynamics, as SMEs may introduce something new, then spend some time refining it. For example, when we asked the CEO of Moira Macs what has been done that was new in the last two years, the reply was:

Our main thrust is in additive reduction in authentic food, and authentic roasting. If you had said four years, I would have included our high-pressure pasteurisation facility that helps us to dramatically reduce additives whilst increasing shelf life. In the last few years we have been refining that process. We have changed our approach to flavour, and this year released 26 new products, with a proportion utilising the preservative free option and new roasting techniques. We are using more authentic ingredients rather than typical food industry flavourings like pre-mixes and blends that are designed for manufacturing convenience - getting back to a more craft approach."

The point to make here is that for SMEs there are a number of temporal factors that influence what is happening at a particular time, consistent with the observations of others (e.g. Allison et al, 2014; Moss et al 2014).

\section{Concluding Remarks}

Chesbrough (2010) had observed that selecting an appropriate business model to support an innovation was critical to its successful deployment. We introduced the thought that viewing SMEs in terms of their dominant business model(s) may allow insights into their innovation orientation and we reviewed case study material collected from some 50 SMEs over the past decade or so. We explored the embedded narratives and the development of these firms over time. We offer a 
complementary viewpoint to that of Chesbrough - that the nature of innovation undertaken by an established firm depends on its dominant business model, and this also influences the nature of networking undertaken. For example contract manufacturing firms regularly network with process technology providers.

We noted a variety of perspectives amongst SMEs on what innovation involved, and clustered these in terms of seven different kinds of business models associated with manufacturing and related service sector firms. We observed that firms may operate more than one business model in parallel (e.g. contract manufacturing and own-product design and manufacture), and that the business models they adopt and adapt may vary over time.

As noted elsewhere in the literature, our SME's generally viewed innovation as anything that makes money, or as the BCA (representing larger firms) defined innovation - the application of knowledge to create additional value and wealth. Inspired by the literature on business models, we suggest this simple definition helps frame opportunities for innovation - is it in what is delivered to customers, where it is delivered or how it is delivered? We have also identified from the case studies that innovation is personal in both small and large firms, needing an innovation champion and cooperation between multiple professions, but adding that incorporating some structure to the management of innovation can be beneficial.

We make three contributions to the literature. Our first contribution, illustrated in figure 2, lies in the recognition that the scale and scope of conditions for continuous innovation within SMEs is dependent upon the both the kind(s) of business models they adopt, and the individual entrepreneurial mindsets of the key owners and managers within the SME. Secondly, the level and type (personal, business, inter-organizational) of purposeful networking undertaken by these owners and/or key managers of the SMEs will influence and be influenced by both of these factors and their innovation orientation. Thirdly, we suggest that the type of business model influences the scope for innovation and viewing firms from this perspective can support better cross-sector comparisons, e.g. comparing similarities and differences in contract production in farming or food processing or electronics or mechanical components.

We have observed some temporal factors associated with the dynamics of SME innovation that may help understand why surveys may give inconsistent results. Firstly, SMEs may not relate their activities to definitions of innovation associated with a particular survey, and secondly, they may not see their current activities as innovative if they are bedding down a change introduced at an earlier time. We have observed that SMEs may change or supplement their business models over time to maintain a competitive position, and that implies they may have to learn about new types of innovation.

Building on the observations of Gilmore, Carson and Grant (2001) that there are linkages between networking activities and learning, we have speculated that the model shown in figure 2 may also be viewed as suggesting multiple generic learning cycles all moderated by networking of some kind, and this could be a topic for future research.

We recognize that our study has limitations commonly associated with qualitative studies and that we only considered a small, non-random sample of manufacturing SMEs. However we suggest the viewpoints presented provide a foundation for further research into the dynamics of SME innovation. 


\section{References}

ABF (2008). Inside the Innovation Matrix: Finding the hidden human dimensions. Australian Business Foundation (editors) (ISBN 978-0-9804138-3-0)

ABS (2012). Australian Bureau of Statistics 2012, Innovation in Australian Business, Cat. No. 8158.0, Commonwealth of Australia, Canberra.

Alexander, A.T. and Childe, S.J. (2013). Innovation: A Knowledge Transfer Perspective. Production, Planning and Control, 24 (2-3), 208-225.

Alguezaui, S and Filieri, R. (2010). Investigating the role of social capital in innovation: sparse versus dense network, Journal of Knowledge Management, Vol. 14 (6), 891-909.

Allison, T. H, McKenny, A, F and Short, J. C. (2014) Integrating Time Into Family Business Research: Using Random Coefficient Modeling to Examine Temporal Influences on Family Firm Ambidexterity. Family Business Review 27: 20- 34

Barjak, F., Niedermann, A. and Perrett, P. (2013). The Need for Innovations in Business Models. European Commission, DG Research and Innovation

BCA (2006). New Concepts in innovation: The keys to a growing Australia, Business Council of Australia, Melbourne.

Beckett, R. C and Gould, R. (2009). Mapping the Innovation Space Characteristics of some Australian Manufacturing SMEs Proceedings of "th Operations, Supply Chain and Services Management Symposium, 810 June, Adelaide, Australia pp 104 - 117 (ISBN 978-0-9806179-3-1)

Berends, H, Jelinek, M, Reymen, I and Stultiëns, R (2013). Product Innovation Processes in Small Firms: Combining Entrepreneurial Effectuation and Managerial Causation. J Product Innovation Management 31(3), 616-635

Bitner, M. J., Ostrom, A., \& Morgan, F. (2008). Service blueprinting: A practical technique for service innovation. California Management Review, 50(3), 66-94

Blackburn, R.A, Hart, M and Wainwright, T. (2013). Small business performance: business, strategy and owner-manager characteristics. Journal of Small Business and Enterprise Development Vol. 20 No. 1, pp. 8-27

Camarinha-Matos, L.M; Afsarmanesh, H and Ollus, M (2005) "ECOLEAD: A holistic approach to creation and management of dynamic virtual organizations" in "Collaborative Networks and their Breeding Environments" Camarinha-Matos, L.M; Afsarmanesh and Ortiz, A (Eds), Springer, USA

Camarinha-Matos, L.M; Afsarmanesh, H; Ermilova, E; Ferrada and Abreu, A (2007) "A reference model for collaborative networks" ECOLEAD Project Report D52. Accessed 10th February 2010. http://www.ve-forum.org/projects/284/Deliverables/D52.3_final.pdf

Carland, J.W, Hoy, F, Boulton W.R and Carland, J.A.C (1984). Differentiating Entrepreneurs from Small Business Owners: A Conceptualization The Academy of Management Review, Vol. 9, No. 2 , pp. 354-359 
Ceci, F. and Iubatti, D. (2012). Personal relationships and innovation diffusion in SME networks: A content analysis approach. Research Policy, 41(3), 565-579.

Chang, Y. Y., Hughes, M., \& Hotho, S. (2011). Internal and external antecedents of SMEs' innovation ambidexterity outcomes. Management Decision, 49(10), 1658-1676.

Chapman, R, Sloan, T and Beckett, R (2008). Operations Excellence. in Samson, D and Sinngh, P.J (Eds) Operations Management - An integrated approach. Cambridge University Press, Melbourne pp $286-322$

Chesbrough, H (2010). Business Model Innovation: Opportunities and Barriers. Long Range Planning 43(2-3), 354-363.

Ci-Rong Li, Chen-Ju Lin \& Han-Chen Huang (2014) Top management team social capital, exploration-based innovation, and exploitation-based innovation in SMEs, Technology Analysis \& Strategic Management, 26(1), 69-85.

Ci-Rong Li, Chen-Ju Lin \& Han-Chen Huang (2014). Top management team social capital, exploration-based innovation, and exploitation-based innovation in SMEs, Technology. Analysis Es Strategic Management, 26(1), 69-85

Coakes, E. and Smith, P. (2007). Developing communities of innovation by identifying innovation champions, The Learning Organization, 14(1), 74-85.

Eisenhardt, K M (1989). Building Theories from Case Research. Academy of Management Review, 14 (4), 532-550.

Gilmore, A., Carson, D., \& Grant, K. (2001). SME marketing in practice. Marketing intelligence \& planning, 19(1), 6-11.

Gronum, S.,Verreynne, M-L. and Kastelle, T. (2012). The Role of Networks in Small and Medium-Sized Enterprise Innovation and Firm Performance. Journal of Small Business Management, 50(2), pp. 257-282

Hickman, C. and Raia, C. (2002). Incubating innovation: Companies must leverage the full spectrum of innovation, from the incremental to the revolutionary. Journal of Business Strategy, 23(3), 14-19

Kastalli, I. V., Van Looy, B., \& Neely, A. (2013). Steering manufacturing firms towards service business model innovation. California management review, 56(1), 100-123

Kelley, D., \& Lee, H. (2010). Managing innovation champions: the impact of project characteristics on the direct manager role. Journal of Product Innovation Management, 27(7), 1007-1019.

Kickul, J. and Gundry, L. K. (2002). Prospecting for Strategic Advantage: The Proactive Entrepreneurial Personality and Small Firm Innovation. Journal of Small Business Management, 40(2), pp. 85-97

Konsti-Laakso, S., Pihkala, T., \& Kraus, S. (2012). Facilitating SME innovation capability through business networking. Creativity and Innovation Management, 21(1), 93-105.

Lasagni, A (2012). How Can External Relationships Enhance Innovation in SMEs? New Evidence for Europe. Journal of Small Business Management, 50(2), 310-339. 
Lewrick, M, Raeside, R and Peisl, T (2007). The Innovators Social Network. Journal of Technology Management $\& 5$ Innovation, 2(3), 38-48.

Loss, L and Crave, S (2011). Agile Business Models: An approach to support collaborative networks. Production, Planning and Control, 22 (5-6), 571-580.

Maglio, P. P. and Spohrer, J. (2013). A service science perspective on business model innovation. Industrial Marketing Management, 42(5), 665-670.

Mason, K and Spring, M (2011). The Sites and Practices of Business Models. Industrial Marketing Management, 40, 1032-1041.

Massa, S., \& Testa, S. (2008). Innovation and SMEs: Misaligned perspectives and goals among entrepreneurs, academics, and policy makers. Technovation, 28(7), 393-407.

Moss, T. W, Payne, T. P and Moore, C.B. (2014) Strategic Consistency of Exploration and Exploitation in Family Businesses. Family Business Review 27(1), 51-71.

Neely, A., Benedettini, O. and Visnjic, I. (2011) The Servitization of Manufacturing Further Evidence. 18th European Operations Management Association Conference, Cambridge, 3-6 July 2011.

O'Donnell, A. (2014). The Contribution of Networking to Small Firm Marketing. Journal of Small Business Management, 52(1), 164-187.

Oslo Manual (2005) Guidelines for Collecting and Interpreting Innovation Data, 3rd Edition OECD, Paris (DOI:10.1787/9789264013100-en)

Osterwalder A and Pigneur Y (2009). Business Model Generation Published by the authors (ISBN: 978-2-8399-0580-0)

Peltier, J. W. and Naidu G.M. (2012). Social networks across the SME organizational lifecycle. Journal of Small Business and Enterprise Development, 19(1), 56-73.

Ritala, P., Armila, L., \& Blomqvist, K. (2009). Innovation orchestration capability-Defining the organizational and individual level determinants. International Journal of Innovation Management, 13(04), 569-591.

Sabatier, V, Mangematin, V and Rousselle, T (2010). From Recipe to Dinner: Business Model Portfolios in the European Biopharmaceutical Industry. Long Range Planning, 43(1), 431-447.

Saunders, M. N., Gray, D. E., Goregaokar, H. (2014). SME innovation and learning: the role of networks and crisis events. European Journal of Training and Development, 38(1/2), 136-149.

Schumpeter, J. A. (1934). The theory of economic development. Cambridge, Mass.: Harvard University Press.

Shamsuzzoha, A., Toscano, C., Carneiro, L. M. Kumar, V. and Helo, P. (2016). ICT-based solution approach for collaborative delivery of customised products. Production, Planning and Control, 27 (4), 280-298.

Shane, S. (1995). Uncertainty avoidance and the preference for innovation championing roles. Journal of International Business Studies, 26(1), 47-68. 
Silvestro, R (1999). Positioning services along the volume-variety diagonal. The contingencies of service design, control and improvement. International Journal of Operations $\&$ Production Management, 19(4), 399-420.

Sosna, M., Trevinyo-Rodriguez, R. N., \& Velamuri, S. R. (2010). Business model innovation through trial-and-error learning: The Naturhouse case. Long Range Planning, 43(2-3), 383-407.

Teece, D.J (2010). Business Models, Business Strategy and Innovation. Long Range Planning, $43(2), 172-19$.

Terziovski, M (2010). Innovation practice and its performance implications in Small and Medium Enterprises (SMEs) in the manufacturing sector: a resource-based view. Strategic Management Journal, 31(8), 892-902.

Unsworth, K., Mazzarol, T. and Reboud, S. (2009). Turning an Innovation Intention into a Reality: The Role of Champions and External Agencies Proceedings of the 23 $3^{\text {rd }}$ ANZAM Conference, Melbourne, 2 - 4 December 2009.

Vincent, L. (2005). Innovation Midwives: Sustaining Innovation Streams in Established Companies. Research-Technology Management, 48(1), 41-49.

Visnjic, I. and Neely, A. (2011). From Processes to Promise: How complex service providers use business model innovation to deliver sustainable growth. Report by the Cambridge Service Alliance. www.cambridgeservicealliance.org

Yin, R.K (2014) Case study research design and methods, Fifth Edition. Sage Publications, Thousand Oaks, California, (ISBN 979-1-4522-4256-0)

Zott, C., \& Amit, R. (2010). Business model design: an activity system perspective. Long range planning, 43(2-3), 216-226. 


\section{Biographies}

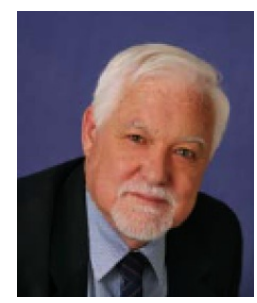

Ronald C. Beckett. Ron Beckett is an industry practitioner with more than 30 years experience in the implementation of creative change and innovation management in Aerospace and Manufacturing. His $\mathrm{PhD}$ explored establishing learning organisation practices in a high technology company. He frequently works at the academia-industry interface, with a focus on Learning to Compete, and lectures in some related Masters degree subjects. Ron is an Adjunct Professor at Swinburne University, and has held similar appointments at several other universities. He has authored or co-authored more than 100 conference papers, journal articles or book chapters related to the pursuit of best practice in extracting value from innovative ideas, knowledge management and effective collaboration implementation.

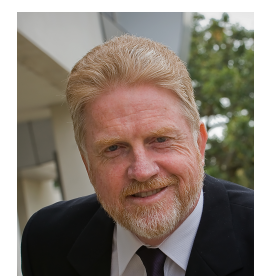

Ross L. Chapman. Ross is Professor of Management and Head of the Management. Marketing and Tourism Department, School of Business and Law at CQUniversity's Sydney Campus. Between May 2010 and January 2014 he was Head of the Deakin Graduate School of Business at Deakin University. Prior to that he spent over 20 years the University of Western Sydney where he was promoted to Professor of Business Systems and was appointed to several positions including Head of School and Associate Dean (Research). Between 1979 and 1985, Ross worked for several large multinational companies in technical, QC/QA and R\&D management positions. He has taught and researched predominantly in the areas of Quality, Innovation and Technology Management. He is author or co-author of 3 books and over 90 book chapters, refereed journal and conference papers in the above areas. Ross has been a Non-Executive Director on the Board of several not-for-profit organisations, and a Board member of the Australian and New Zealand Academy of Management (ANZAM) for over 7 years, including the 2011 President.

\section{ISSN 2183-0606}

http://www.open-jim.org

http://creativecommons.org/licenses/by/3.0 